Instante igitur hora comedendi et fame ${ }^{4}$ pauperes Christi cruciante dixit pater sanctus ad socium. Iuxts hunc lapidem karissime alterutrum expectemus cum pro divino amore elemosinam collegerimus mendicatam. Sicque divisi ab invicem vicos et plateas circueunt pulsant hostis domorum terunt limina elemosinam confidenter petant reverenter oblata suscipiunt. Dum autem vir deo devotus frater Bernhardus nimia famis inedia grassaretur nihil collegit. Sed quam cito micas at crustas vel buccelas ab offerentibus accepit totum tam cito comedit. Sicque rediens ad predictum lapidem de elemosina omnino nihil secum detulit. Veniens itsque pater Franciscus collectam secum elemosinam portans ostendit socio dicens. Ecce frater mi elemosina quam mihi [359a] divina largitas donavit. Et tu siquid habuisti appone ut in dei nomine pariter manducemus. Tunc frater Bernhardus timore perterritus ad pedes pii patris humiliter se prostravit dicens. Sancte pater confiteor peccatum meum. Nihil de elemosina mecum sustuli sed oblatum mox comedi quia valde esurivi. Hoc audiens S. Franciscus pre gaudio lacrimis irrigatus amplexans fratrem Bernhardum magna voce clamavit. Vere beacior me es o fili dulcissime. Tu es vere perfectus sacri evangelii observator. Quia nihil congregasti nec aliquid tibi in crastinum reservasti sed cogitatum tuum in domino totum iactasti.

\title{
Proposals for an Agreement with Scotland, c. 1363
}

The annexed document (Public Record Office, Exch. T. R. Scottish Documents, 2/17) appears to have escaped the notice of Mr. Joseph Bain. I am inclined to fix the date about 1363 and to regard it as a portion of the negotiations between David $\Pi$ and Edward III which resulted in the abortive project for the recognition of Edward as heir to the Scottish throne. 1

Charles Jomason.

[Chirographum.]

Memorandum quod pro bono pacis pro omni clamoo homagii renunciando pro terrarum per Regem Anglie occupatarum restitucione Et pro successione relinquenda illis de Regno Scocie quibus de inre debetur iste vie in generali tacte per privata consilia fuerunt et locute. Prima via fuit quod exheredatis sue terre in Regno Scocie existentes concederentur et aliquibus aliis personis per Regem Anglie nominandis certe terre de Regno Scocie darentur pro quibus Regi Scocie homagium ot serviciam debitum facerent, et facore tenerentur. Secunda via quod per Regnum Scocie Regi Anglie de certo numero hominum ad certum tempus subveniretur. Tercia via quod ultra solucionem pecunie pro redempcione Regis Scacio debite pro bono pacis et terrarum per Regem Anglie omnino (?) restituendarum certa summa pecunie daretur secundum quod inter tractantes poterit concordari Et si sic tractantes (?) in nulla via istarum viarum ad plenum poterunt concordari via alia esset partes concordando de qualibet viarum predictarum.

- MS. fama.

CF. Bain, Cal of Doctuments relating to Scottand, IV, p. xiii and Nos, 91 and 92. 